УДК 621.373.826.032:534.232.082.73

Р. В. Трембовецька, к.т.н., доцент,

e-mail: r.trembovetska@chdtu.edu.ua

В. В. Тичков, к.т.н., стариий викладач,

Ю. А. Петрушко, магістрант

Черкаський державний технологічний університет

б-р Шевченка, 460, м. Черкаси, 18006, Україна

\title{
ДОСЛІДЖЕННЯ БАГАТОКОМПОНЕНТНОЇ ОПТИЧНОЇ СИСТЕМИ ДЛЯ СВІТЛО-ЛАЗЕРНОЇ ТЕРАПІї
}

В роботі представлено один із методів розрахунку двокомпонентної оптичної системи, а саме матричний метод. Розглянуто різноманітні варіачї розташування оптичних елементів: опромінюваний об'єкт розтамований у нескінченності; джерело світла розтамоване в передній фокальній площині освітлювальної системи; оптична система проектує джерело світла безпосередньо на освітлювальний об'єкт; освітлювальна система утворює зображення джерела в площині вхідної зіниці оптичної системи. Основна мета - підбір оптичної системи, яка буде відповідати вимогам технічного завдання. Проведено розрахунок та аналіз декількох схем двокомпонентної позитивної оптичної системи. Встановлено умови, за яких можливе виконання вимог технічного завдання, та відібрано найкращу, що задовольняе їм.

Ключові слова: світлолікування (фототерапія), спектр випромінювання, світлодіод, довжина хвилі, потужність випромінювання, оптична система, матричний метод розрахунку.

Постановка проблеми. Прогрес медичної науки і техніки значною мірою визначається досягненнями в галузі оптичної електроніки. На сьогодні в медичній практиці все більше застосовуються немедикаментозні методи функціональної регулюючої терапії, що грунтуються на взаємодії випромінювання оптичного діапазону 3 біологічними об' єктами. Оптико-електронна медична апаратура на основі лазерів, світловипромінюючих діодів, теплових та газорозрядних випромінювачів оптичного спектрального діапазону має невичерпні можливості при лікуванні хворих із різноманітними захворюваннями.

Клас низькоінтенсивних напівпровідникових лазерів та світловипромінюючих діодів у видимому та ближньому ІЧ діапазоні спектра все більше застосовується в медичній практиці внаслідок суттєвого розширення можливостей методик проведення процедур і терапевтичної ефективності.

Аналіз джерел досліджень і публікацій. Світлолікування (фототерапія) - використання $з$ лікувальною і профілактичною метою електромагнітних коливань оптичного діапазону (світла), які включають інфрачервоне, видиме і ультрафіолетове випромінювання.

Світло може впливати на організм двома шляхами - через орган зору або через шкіру.
Як відомо, шкіра людини - це багатокомпонентне мутне біологічне середовище, оптичні характеристики якого залежать від декількох факторів [1]:

- фізіологічного стану;

- рівня гідратації, гомогенності, видової варіативності.

Оскільки біологічна тканина оптично неоднорідна із середнім показником заломлення > 1, тому на границі розділу шкіраповітря частина випромінювання відбивається. За даними роботи [1], коефіцієнт відбиття залежить як від довжини хвилі випромінювання, так і від типу шкіри.

Внаслідок поглинання інтенсивність падаючої хвилі зменшується при проходженні крізь «мутне» середовище. Можливість речовини поглинати випромінювання залежить від декількох факторів: електронного складу іiі атомів і молекул, довжини хвилі випромінювання, товщини поглинаючого шару та внутрішніх параметрів (температури та концентрації поглинаючих центрів).

В біологічних тканинах поглинання викликано молекулами води або макромолекулами. Одними з основних біологічних поглиначів $\epsilon$ меланін та гемоглобін. Відоме «терапевтичне вікно» (600-1200 нм), де вода і макромолекули слабко поглинають випромінювання. В спектральному діапазоні «терапевти- 
чного вікна» випромінювання проникає 3 мінімальними перешкодами в біологічні тканини, що використовують для лікування глибоких тканинних структур. Таким чином, ступінь поглинання визначає кінцевий результат світло-лазерної дії [2-3].

Для точного визначення ступеня поглинання тими чи іншими органами та структурами необхідно знати оптичний коефіцієнт поглинання тканин, що розглянуто в роботах [2-5].

Для взаємодії світла 3 біологічними об'єктами важливими є: час опромінення, режим опромінення (безперервний або імпульсний), періодичність і тривалість впливу. Фізіологічна і лікувальна дія оптичного випромінювання визначається декількома факторами, серед яких найважливішими $є$ довжина хвилі використаного випромінювання і тривалість діiі. Метою світло-лазерного опромінення $\epsilon$ введення енергії випромінювання в локальний об'єм тканини і стимулювання в ній необхідних фотохімічних або теплових процесів, які дають сприятливий медичний ефект. Очевидно, що чим більша частка енергії випромінювання поглинається у виділеному об'ємі тканини, тим досконаліша медична процедура. $[6-7,10]$

Особливість такої терапії є наступною

- потужність випромінювання, необхідна для сприйняття організмом, потрапляє в область нетеплової дії;

- нормалізуючий фізіологічний ефект зберігається і після припинення дії; тривалість збереження ефекту збільшується від сеансу до сеансу;

- лікувальний ефект спостерігається в осередку патології, проте дія може виконуватися у віддаленій від запалення зоні.

Таким чином, необхідно розробити оптичну систему, яка буде перетворювати оптичне випромінювання від світлодіода в зону розміром 10-15 мм на біологічному об' єкті із рівномірною щільністю розподілу по зоні.

Мета роботи - дослідження багатокомпонентної оптичної системи.

Постановка задачі. Одним із основних елементів розроблювальної системи є освітлювальна система, яка призначена для створення необхідної освітленості опромінюваного об' єкта. Вона повинна зібрати максимально можливу частину загального світлового потоку, що дає джерело світла, та забезпечити необхідний напрямок. ди [8]:

Як джерело світла вибираємо світлодіо-

\begin{tabular}{|c|c|c|}
\hline № & $\begin{array}{c}\text { Тип світло- } \\
\text { діода }\end{array}$ & Параметри \\
\hline 1 & $\begin{array}{l}\text { C3535M- } \\
\text { ANF1- } \\
\text { E1H11N }\end{array}$ & $\begin{array}{c}\text { 585-590 nm = жовтий, } \\
\text { 45,7 lm, } 125 \text { град., } \\
3,45 \cdot 3,45 \mathrm{~mm}\end{array}$ \\
\hline 2 & $\begin{array}{c}\text { C3535M- } \\
\text { DNL1- } \\
\text { A1J11H } \\
\end{array}$ & $\begin{array}{l}440-445 \mathrm{~nm}=\text { дійсний } \\
\text { синій, 560-600 mW, } \\
125 \text { град., } 3,45 \cdot 3,45 \mathrm{~mm}\end{array}$ \\
\hline 3 & $\begin{array}{l}\text { C3535M- } \\
\text { DNL1- } \\
\text { A1J11H }\end{array}$ & $\begin{array}{c}445-450 \mathrm{~nm}=\text { дійсний } \\
\text { синій, } 600-650 \mathrm{~mW}\end{array}$ \\
\hline 4 & $\begin{array}{l}\text { C3535M- } \\
\text { GNL1- } \\
\text { A1G11H }\end{array}$ & $\begin{array}{c}520-525 \mathrm{~nm}=\text { зелений, } \\
80,6-87,4 \mathrm{~lm}, 125 \text { град., } \\
3,45 \cdot 3,45 \mathrm{~mm}\end{array}$ \\
\hline 5 & $\begin{array}{l}\text { C3535M- } \\
\text { RNL1- } \\
\text { E1H11N }\end{array}$ & $\begin{array}{c}\text { 620-625nm = червоний } \\
56,8-62,01 \mathrm{~lm}, 125 \text { град., } \\
3,45 \cdot 3,45 \mathrm{~mm}\end{array}$ \\
\hline 8 & $\begin{array}{l}\text { C3535X- } \\
\text { FNL1- } \\
\text { E1H11N }\end{array}$ & $\begin{array}{c}\text { 730-740nm = інфра- } \\
\text { червоний, 440-480 mW, } \\
3,45 \cdot 3,45 \mathrm{~mm}\end{array}$ \\
\hline 9 & $\begin{array}{l}\text { C3535X- } \\
\text { INA1- } \\
\text { E1D11N }\end{array}$ & $\begin{array}{l}850-860 \mathrm{~nm}=\text { інфра- } \\
\text { червоний, 200-240 mW, } \\
80 \mathrm{deg} .\end{array}$ \\
\hline 10 & $\begin{array}{l}\text { C3535X- } \\
\text { JNL1- } \\
\text { E1H11N }\end{array}$ & $\begin{array}{c}925-955 \mathrm{~nm}=\text { інфра- } \\
\text { червоний, } 400-560 \mathrm{~mW} \\
140 \mathrm{deg}\end{array}$ \\
\hline
\end{tabular}

До основних переваг світловипромінюючих діодів можна віднести: більш високу концентрацію потоку оптичного випромінювання у відносно малому тілесному куті, вузький спектральний склад, високий ККД, менші габарити, енергоспоживання, тепловідведення.

Для опромінення об'єкта кінцевого розміру можна застосувати такі схеми:

- опромінюваний об'єкт розташований у нескінченності; джерело світла розташоване в передній фокальній площині освітлювальної системи;

- оптична система проектує джерело світла безпосередньо на освітлювальний об'єкт;

- освітлювальна система утворює зображення джерела в площині вхідної зіниці наступної оптичної системи.

Таким чином, для збільшення потоку випромінювання, що спрямовується від джерела на освітлювальний об'єкт, необхідно застосувати спеціальні оптичні елементи конденсори. 
Із трьох можливих схем для цієї мети найкраще застосувати третю схему, яка дасть можливість у певних межах варіювати розміром зони (10-15 мм). Застосовуємо конденсор, який створює дійсне зображення джерела світла на кінцевій відстані від оптичної системи. Зазвичай конденсори складаються тільки з позитивних лінз, тому вони мають значні сферичні та хроматичні аберації, які збільшуються із кутом охоплення $2 \sigma$ та лінійним збільшенням $\beta$.

Оскільки конструкція світлодіода припускає вбудовану лінзу [8], то другим елементом конденсора можна використати лінзу -
LL01CR-DF60L06-M2-T, що має $35^{\circ}$ (50\%int), $60^{\circ}$ (90\%int), $\mathrm{D}=13,0 \mathrm{~mm}, \mathrm{~h}=7.1 \mathrm{~mm}$ [9].

На рис. 1 зображено схему, яка буде використовуватися для аналізу оптичних схем. Складна двокомпонентна система складається 3 декількох простих систем, які задані положенням фокусів $f^{\prime}$ та головних площин $H H^{\prime}$, взаємне розташування яких задається відстанню $d_{1}$ - відстань між задньою головною площиною попереднього компонента і передньою головною площиною наступного.

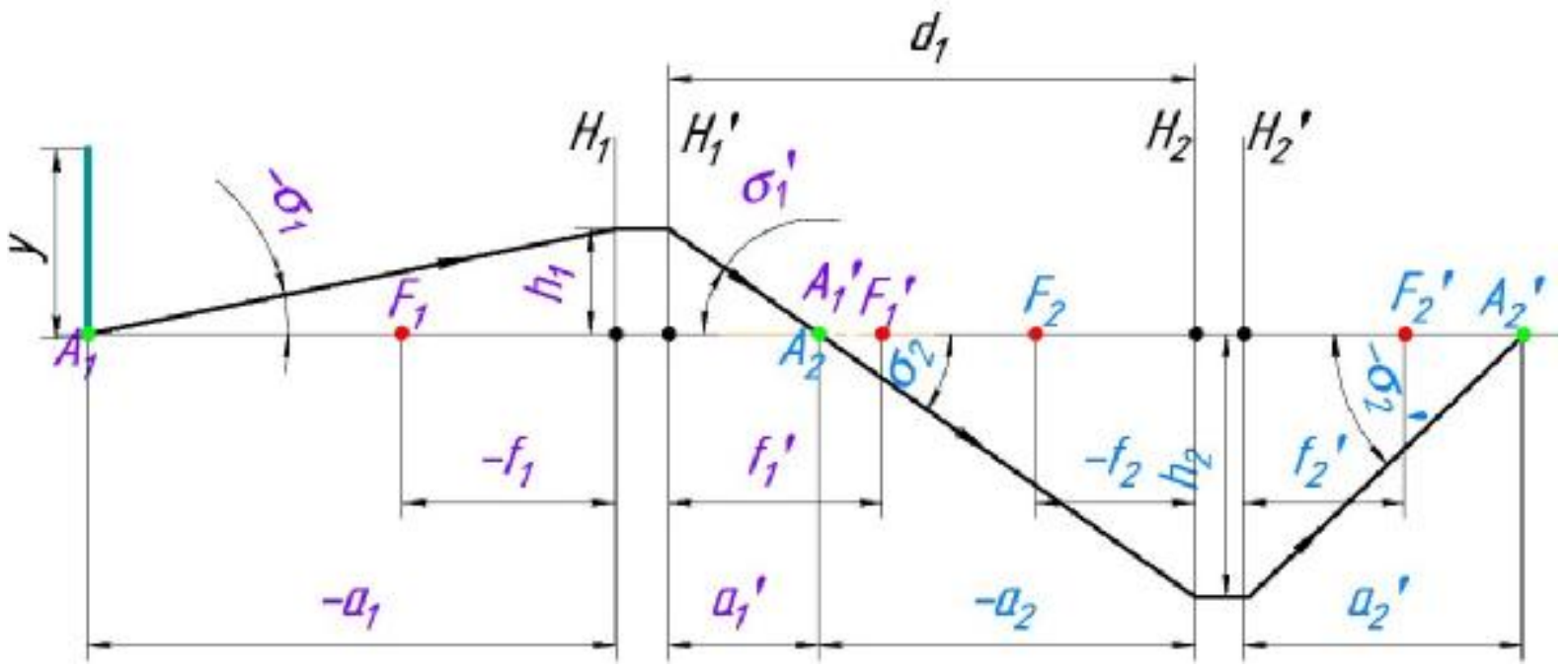

Рис. 1. Оптична схема для розрахунку двокомпонентної системи:

y - розмір предмета (в цьому випадку розмір випромінюючої площадки світлодіода); $a_{1}$ - відстань від предмета до першого оптичного компонента; $\sigma_{1}$ - апертурний кут в області предмета (в цьому випадку приймаємо кут випромінювання світлодіода); $a_{1}^{\prime}$ - відстань від об'єктива до площини аналізатора; $a_{2}^{\prime}$ - відстань, що визначає положення точки зображення $A_{2}^{\prime}$, яка утворюється еквівалентною системою; $f_{1}^{\prime}=-f_{1}-$ відповідно задня та передня фокусні відстані першого оптичного компонента;. $h_{1}, h_{2}$ - висота падіння променя на оптичний компонент

Для визначення відстаней $a_{1}^{\prime}, a_{2}, a_{2}^{\prime}$ та розміру зображення $y^{\prime}$ використовуємо матричний метод розрахунку оптичних систем [11]. Параметри променя в просторі предметів і зображення можуть бути задані тільки в тому випадку, якщо вибрані опорні площини. Тому задаємо опорні площини: ОП1 характеризує положення предмета відносно передньої головної площини $\mathrm{H}_{1}$; ОП2, ОП3 - розташовані в головних площинах першого оптичного компонента; ОП4 - характеризує положення проміжного зображення, яке утворюється першою лінзою; ОП5, ОП6 - розташовані в головних площинах другого компонента; ОП7 - характеризує положення зображення відносно задньої головної площини $H_{2}^{\prime}$ (рис. 2). 


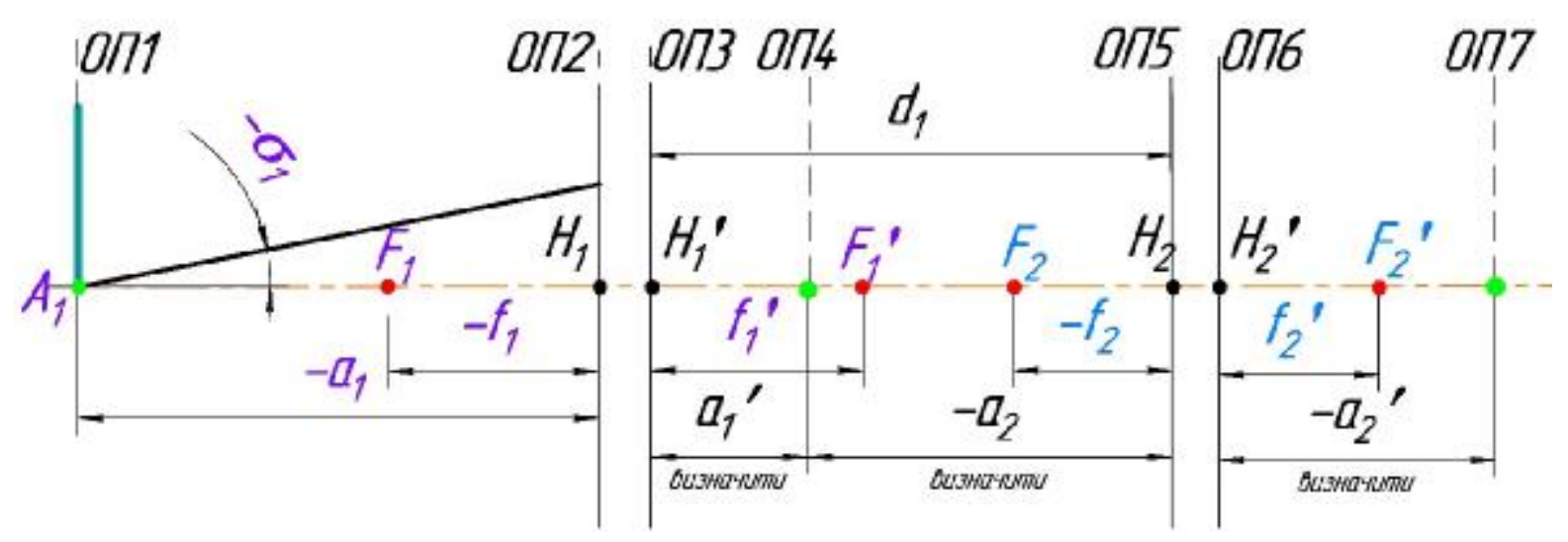

Рис. 2. Розташування опорних площин

Розраховуємо параметри вихідного променя за заданими параметрами вхідного для першого компонента.

$$
M_{1}=\mathfrak{I}_{2} \cdot M_{H 1} \cdot \mathfrak{I}_{1}
$$

де $M_{H 1}=\left(\begin{array}{cc}1 & 0 \\ -\frac{1}{f_{1}^{\prime}} & 1\end{array}\right)$ - матриця заломлення головних площин першої лінзи;

$$
\mathfrak{I}_{2}=\left(\begin{array}{cc}
1 & a_{1}^{\prime} \\
0 & 1
\end{array}\right), \mathfrak{I}_{1}=\left(\begin{array}{cc}
1 & -a_{1} \\
0 & 1
\end{array}\right)-\text { матриця }
$$

переносу в області зображення та предмета відповідно.

Розв'язавши матрицю (1), отримаємо такі коефіцієнти:

$$
\begin{gathered}
A_{1}=1-\frac{a_{1}^{\prime}}{f_{1}^{\prime}} ; B_{1}=-\left(1-\frac{a_{1}^{\prime}}{f_{1}^{\prime}}\right) \cdot a_{1}+a_{1}^{\prime} \\
C_{1}=\frac{-1}{f_{1}^{\prime}} ; D_{1}=1+\frac{a_{1}}{f_{1}^{\prime}}
\end{gathered}
$$

Як видно 3 отриманих результатів, коефіцієнти $\mathrm{A}_{1}, \mathrm{~B}_{1}, \mathrm{C}_{1}, \mathrm{D}_{1}$ містять невідомий параметр $a_{1}^{\prime}$. Для його визначення необхідно

$$
B_{1}=-\left(1-\frac{a_{1}^{\prime}}{f_{1}^{\prime}}\right) \cdot a_{1}+a_{1}^{\prime}=0 \Rightarrow a_{1}^{\prime} .
$$

Це правило застосовують у тому випадку, коли як опорні площини вибрані оптично спряжені площини ОП1 та ОП4. Тоді коефіцієнт А показує лінійне збільшення оптичної системи, C - оптичну силу системи, D - кутове збільшення оптичної системи.

Розраховуємо параметри вихідного променя за заданими параметрами вхідного для двокомпонентної оптичної системи.
Для такого розташування опорних площин загальна матриця перетворення буде складатися 3 окремих матриць перенесення зображення та матриць заломлення між головними площинами [7]:

$$
M=\mathfrak{I}_{2} \cdot M_{H 2} \cdot \mathfrak{I} \cdot M_{H 1} \cdot \mathfrak{I}_{1}
$$

де $M_{H 1}=\left(\begin{array}{cc}1 & 0 \\ -\frac{1}{f_{1}^{\prime}} & 1\end{array}\right)$ - матриця заломлення головних площин першої лінзи;

$M_{H 2}=\left(\begin{array}{cc}1 & 0 \\ -\frac{1}{f_{2}^{\prime}} & 1\end{array}\right)-$ матриця заломлення головних площин другої лінзи;

$\mathfrak{I}_{2}=\left(\begin{array}{cc}1 & a_{2}^{\prime} \\ 0 & 1\end{array}\right), \mathfrak{I}_{1}=\left(\begin{array}{cc}1 & -a_{1} \\ 0 & 1\end{array}\right) \quad-\quad$ матриця переносу в області зображення та предмета відповідно

$\mathfrak{I}=\left(\begin{array}{ll}1 & d \\ 0 & 1\end{array}\right) \quad-\quad$ матриця переносу між лінзами.

Оскільки в виразі (2) маємо перемноження матриць, то принципово записати в рівнянні окремі матриці у зворотному порядку порівняно з прийнятою для них нумерацією.

Розв'язавши цю матрицю, отримаємо такі коефіцієнти:

$$
A=1-\frac{a_{2}^{\prime}}{f_{2}^{\prime}}-\frac{\left(1-\frac{a_{2}^{\prime}}{f_{2}^{\prime}}\right) \cdot d+a_{2}^{\prime}}{f_{1}^{\prime}} ;
$$




$$
\begin{gathered}
B=-\left[1-\frac{a_{2}^{\prime}}{f_{2}^{\prime}}-\frac{\left(1-\frac{a_{2}^{\prime}}{f_{2}^{\prime}}\right) \cdot d+a_{2}^{\prime}}{f_{1}^{\prime}}\right] \cdot a_{1}+ \\
+\left(1-\frac{a_{2}^{\prime}}{f_{2}^{\prime}}\right) \cdot d+a_{2}^{\prime} ; \\
\left.C=\frac{-1}{f_{2}^{\prime}}-\frac{\left(\frac{-1}{f_{2}^{\prime}} \cdot d+1\right.}{f_{1}^{\prime}}\right) \\
D=-\left[\frac{-1}{f_{2}^{\prime}}-\frac{\left(\frac{-1}{f_{2}^{\prime}} \cdot d+1\right.}{f_{1}^{\prime}}\right] \cdot a_{1}- \\
-\frac{1}{f_{2}^{\prime}} \cdot d+1
\end{gathered}
$$

Для визначення невідомого параметра $a_{2}^{\prime}$, як було показано вище, коефіцієнт В прирівнюємо до нуля і 3 отриманого рівняння визначаємо $a_{2}^{\prime}$ :

$$
a_{2}^{\prime}=\frac{\left(a_{1} \cdot f_{1}^{\prime}-a_{1} \cdot d-d \cdot f_{1}^{\prime}\right) \cdot f_{2}^{\prime}}{\left(\begin{array}{l}
a_{1} \cdot f_{1}^{\prime}-a_{1} \cdot d+a_{1} \cdot f_{2}^{\prime}- \\
-d \cdot f_{1}^{\prime}+f_{1}^{\prime} \cdot f_{2}^{\prime}
\end{array}\right)} .
$$

Тоді координати вихідного променя визначаються:

$$
\left(\begin{array}{c}
y^{\prime} \\
V^{\prime}
\end{array}\right)=\left(\begin{array}{ll}
A & B \\
C & D
\end{array}\right) \cdot\left(\begin{array}{c}
y \\
V
\end{array}\right),
$$

де $\left(\begin{array}{c}y^{\prime} \\ V^{\prime}\end{array}\right),\left(\begin{array}{c}y \\ V\end{array}\right)$-стовпчики матриці вихідного і вхідного променів відповідно.

$V=n \cdot \sigma-$ кутова координата.

Застосовуємо формули (1)-(5) для аналізу двокомпонентних оптичних систем з такими параметрами:

\begin{tabular}{|c|c|c|c|c|}
\hline$y^{\prime}$, мм & $d_{1}$, мм & $a_{2}^{\prime}$, мм & $\begin{array}{c}\mathrm{D}_{12}, \\
\text { мМ }\end{array}$ & $\begin{array}{c}\mathrm{L}, \\
\text { мм }\end{array}$ \\
\hline $10-15$ & $60 \pm 5$ & до 100 & 11 & до 70 \\
\hline
\end{tabular}

Схема 1. Вихідні дані

\begin{tabular}{|l|c|c|c|l|l|}
\hline$y$, & $f_{1}^{\prime}$, & $f_{2}^{\prime}$, & $d_{1}$, & $a_{1}$, & $\sigma_{1}$, \\
мм & мм & мм & мм & мм & градyс \\
\hline 1.3 & 16 & 14 & 60 & -25 & -60 \\
\hline
\end{tabular}

Результат розрахунку

\begin{tabular}{|c|c|c|c|}
\hline$y^{\prime}, M M$ & $a_{2}^{\prime}, M M$ & $\mathrm{~h}_{\max }, \mathrm{MM}$ & $\mathrm{L}, \mathrm{MM}$ \\
\hline 7,1 & 57 & 43 & 88 \\
\hline
\end{tabular}

Як видно, за параметрами $y^{\prime}$ та $a_{2}^{\prime}$

\begin{tabular}{|c|c|c|c|c|c|}
\hline $\begin{array}{l}y, \\
\mathcal{M M}\end{array}$ & $\begin{array}{l}f_{1}^{\prime}, \\
\text { MM }\end{array}$ & $\begin{array}{l}f_{2}^{\prime} \\
\mathcal{M M}\end{array}$ & $\begin{array}{l}d_{1}, \\
M M\end{array}$ & $\begin{array}{l}a_{1}, \\
\text { MM }\end{array}$ & $\begin{array}{l}\sigma_{1}, \\
\text { градус }\end{array}$ \\
\hline 1.3 & 9,5 & 16 & 57 & -13 & -60 \\
\hline \multicolumn{6}{|c|}{ Результат розрахунку } \\
\hline$y^{\prime}, M M$ & \multicolumn{2}{|c|}{$a_{2}^{\prime}, M M$} & \multicolumn{2}{|c|}{$\mathrm{h}_{\max }, \mathrm{MM}$} & L, MM \\
\hline 9,88 & \multicolumn{2}{|c|}{61} & \multicolumn{2}{|c|}{23} & 70 \\
\hline
\end{tabular}
отримані дані задовольняють вимогам технічного завдання, проте для повного використання світлового потоку потрібна лінза 3 діаметром 86 мм, в противному випадку частина потоку буде втрачатися.

Схема 2. Вихідні дані

Результат аналогічний, як і для схеми 1.

Схема 3. Вихідні дані

\begin{tabular}{|l|l|l|l|l|l|}
\hline$y$, & $f_{1}^{\prime}$, & $f_{2}^{\prime}$, & $d_{1}$, & $a_{1}$, & $\sigma_{1}$, \\
мм & мм & мм & мм & мм & градус \\
\hline 1.3 & 16 & 13,4 & $25 \pm 5$ & -13 & -60 \\
\hline
\end{tabular}

Результат розрахунку

\begin{tabular}{|c|c|c|c|}
\hline$y^{\prime}$, MM & $a_{2}^{\prime}$, MM & $\mathrm{h}_{\max }, \mathrm{MM}$ & $\mathrm{L}, \mathrm{MM}$ \\
\hline 1,134 & 15,59 & 33 & 95 \\
\hline
\end{tabular}

Як видно, всі параметри не задовольняють технічному завданню. Змінюючи відстань між компонентами від 26 до 31 мм, маємо зменшення зображення, при цьому відстань $a_{2}^{\prime}=15,47$ мм майже не змінюється.

Встановимо, як впливає фокусна відстань другого компонента на відстань $\mathrm{L}$ та розмір зони зображення.

Схема 4. Збільшуємо фокусну відстань $f_{2}^{\prime}$, всі інші параметри залишаємо без змін.

Вихідні дані

\begin{tabular}{|l|l|l|l|l|l|}
\hline$y$, & $f_{1}^{\prime}$, & $f_{2}^{\prime}$, & $d_{1}$, & $a_{1}$, & $\sigma_{1}$, \\
Mм & мм & Mм & Mм & мм & градyс \\
\hline 1.3 & 16 & 45 & $25 \pm 5$ & -13 & -60 \\
\hline
\end{tabular}


Результат розрахунку

\begin{tabular}{|c|c|c|c|}
\hline$y^{\prime}$, MM & $a_{2}^{\prime}$, MM & $\mathrm{h}_{\max }, \mathrm{MM}$ & $\mathrm{L}, \mathrm{MM}$ \\
\hline 6,199 & 85,23 & 32 & 180 \\
\hline
\end{tabular}

Як видно, за параметрами $y^{\prime}$ та $a_{2}^{\prime}$ отримані дані задовольняють вимогам Т3, проте, як і в попередніх схемах, потрібна лінза великого діаметра. Також маємо загальне збільшення розміру L оптичної насадки майже в два рази.

В усіх чотирьох схемах не задовольняється вимога рівномірності освітлення по зоні зображення.

Для усунення цього недоліку необхідно зменшити кут розходження пучка після другого компонента. Цю вимогу можна досягти, використовуючи одну з властивостей фокальних площин. Тобто для забезпечення мінімального розходження пучка після оптичної насадки необхідно сумістити зображення, що утворено першим оптичним компонентом, i3 передньою фокальною площиною другого компонента. Виконаємо цю умову для розрахунків наступної схеми.

При цьому розмір паралельного пучка значною мірою обумовлюється відстанню між компонентами d. Чим більша відстань, тим більший розмір пучка, i, відповідно, для максимального використання світлового потоку необхідна лінза великих розмірів. Тому для подальших розрахунків визначимо цю відстань, щоб задовольнити вимоги технічного завдання за параметром $\mathrm{D}_{12}=11$ мм. На загальний розмір оптичної насадки впливає проміжне зображення першого компонента і для зменшення відстані $a_{1}^{\prime}$ необхідно, щоб виконувалася вимога $\left|f_{1}\right|>\left|a_{1}\right|$.

Схема 5. Вихідні дані

\begin{tabular}{|l|l|l|l|l|l|}
\hline$y$, & $f_{1}^{\prime}$, & $f_{2}^{\prime}$, & $d_{1}$, & $a_{1}$, & $\sigma_{1}$, \\
мм & мм & мм & мм & мм & градус \\
\hline 1.3 & 10 & - & 2 & $-3,5$ & -60 \\
\hline
\end{tabular}

Щоб визначити фокусну відстань $f_{2}^{\prime}$, необхідно:

- Із формули (2) визначити відстань, де утворюється проміжне зображення першого компонента:

$$
a_{1}^{\prime}=\frac{a_{1}}{a_{1}+f_{1}^{\prime}} \cdot f_{1}^{\prime}=-5.38 \text { м. } .
$$

- Відстань до другої лінзи:

$$
a_{2}=a_{1}^{\prime}-d=7.38 \mathrm{MM} .
$$

Тоді відповідно фокусна відстань повинна бути $f_{2}^{\prime}=a_{2}$.

Результат розрахунку рис. 3:

- Розмір першої лінзи

$$
D_{1}=2 \cdot a_{1} \cdot \operatorname{tg}\left(\sigma_{1}\right)=12 \text { мм. }
$$

- Розмір другої лінзи і, відповідно, паралельного пучка променів

$$
D_{2}=2 \cdot a_{2} \cdot \operatorname{tg}\left(\sigma_{2}\right)=16,47 \mathrm{M \mu} \text {. }
$$

Оскільки пучок після другої лінзи паралельний, то відстань $a_{2}^{\prime}$ не встановлюється. Загальна довжина насадки без урахування елементів та конструкції закріплення приблизно 20 мм, як видно із рис. 3, обумовлюється фокусними відстанями першої лінзи.

Оптична система, що побудована за принципом суміщення проміжного зображення і передньої фокальної площини другого компонента (рис. 3), не має можливості регулювання розміру зони, оскільки фокусна відстань $f_{2}^{\prime}$ безпосередньо залежить від відстані між компонентами d. Якщо ж виконати переміщення одного компонента відносно іншого в межах \pm 5 мм при всіх інших фіксованих параметрах, то маємо, як і в схемах 1-4, нерівномірність опромінення по зоні зображення. Цей розрахунок необхідно перевірити на фізичну можливість виготовлення конструктивних параметрів лінз та уточнити розмір $\mathrm{d}$.

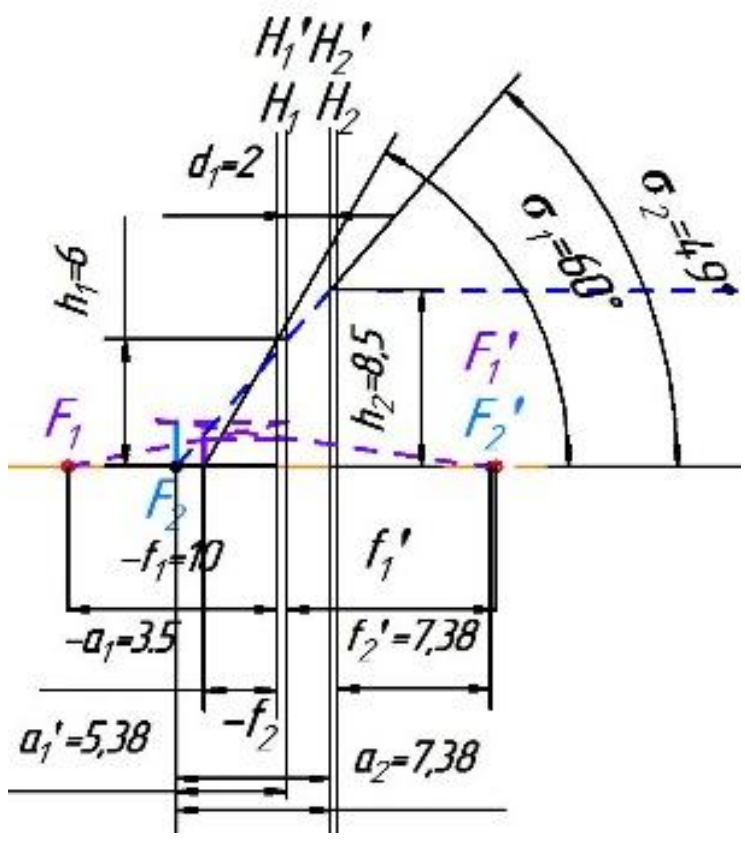

Рис. 3. Розрахована двокомпонентна оптична схема 5 
Висновки. В роботі виконано розрахунок та аналіз двокомпонентної оптичної системи, яка складається з позитивних лінз. Запропоновано використовувати матричний метод розрахунку оптичної багатокомпонентної системи. Із розрахунків видно, що жодна iз запропонованих схем не відповідає повністю вимогам технічного завдання. Схема 5 задовольняє вимогам технічного завдання за геометричним розміром лінз та рівномірністю зони опромінення. Цей розрахунок необхідно перевірити на фізичну можливість виготовлення конструктивних параметрів лінз і уточнити відстань між лінзами.

Для заданого типу джерела світла використовувати двокомпонентну оптичну систему із позитивних лінз недоцільно. Таким чином, можна обрати світловипромінюючі джерела 3 іншою діаграмою спрямованості, які також необхідно перевірити розрахунком на відповідність технічному завданню.

В подальшому необхідно проаналізувати можливість використання двокомпонентної системи, що складається з від'ємної та позитивної лінзи, використовуючи запропоновану методику матричного розрахунку.

Запропонований матричний метод розрахунку можна використовувати для дослідження оптичних систем будь-якої складності 3 різноманітними схемами (послідовностями) розташування оптичних елементів.

\section{Список літератури}

1. Пушкарева А. Е. Методы математического моделирования в оптике биоткани: учеб. пособие. Санкт-Петербург: СПбГУ ИТМО, 2008. 103 c.

2. Серебряков В. А. Опорный конспект лекций по курсу «Лазерные технологии в медицине». Санкт-Петербург: СПбГУ ИТМО, 2009. $266 \mathrm{c.}$

3. Смирнов А. П., Абрамов Д. А., Пименов А. Ю. Компьютерное моделирование оптических систем: учеб. пособие. СанктПетербург: СПбГУ ИТМО, 2012. 84 с.

4. Кузнецов К. А., Колчигин Н. Н., Коваленко И. Ф., Шкорбатов Ю. Г. Исследование реакций клеток человека на воздействие низкоинтенсивного микроволнового излучения и постоянного магнитного поля. Применение лазеров в медииине и биологии: материалы XLVI Меж- дунар. науч.-практ. конф. Харьков, 2017. C. $83-85$.

5. Трембовецкая Р. В. Анализ взаимодействия лазерного излучения с биологическими тканями. Вісник Черкаського державного технологічного університету. Серія: Технічні науки. 2012. №.4. C. 101-104.

6. Буйлин В. А., Ларюшин А. И., Никитина М. В. Свето-лазерная терапия: руководство для врачей. Тверь: Триада, 2004. $256 \mathrm{c}$.

7. Улащик В. С., Лукомский И. В. Общая физиотерапия: учебник. 3-е изд., стереотип. Минск: Книжный Дом, 2008. 512 с.

8. URL: www.ledlink-optic.com

9. URL: www.tslc.com.tw

10. Беликов А. В., Скрипник А. В. Лазерные биомедицинские технологии: учеб. пособие. Ч. 1. Санкт-Петербург: СПбГУ ИТMO, 2008. 116 c.

11. Салех Б., Тейх М. Оптика и фотоника. Принципы и применения. 2012. Т. 2. Долгопрудный: Интеллект, 784 с.

\section{References}

1. Pushkareva, A. Ye. (2008) Methods of mathematical modeling in biotissue optics. St. Petersburg: SPbGU ITMO, 103 p. [in Russian].

2. Serebryakov, V. A. (2009) A basic summary of lectures on the course «Laser technologies in medicine». St. Petersburg: SPbGU ITMO. 266 p. [in Russian].

3. Smirnov, A. P., Abramov, D. A., Pimenov A. Yu. (2012) Computer modeling of optical systems. St. Petersburg: SPbGU ITMO. 84 p. [in Russian].

4. Kuznetsov, K. A., Kolchigin, N. N., Kovalenko, I. F., Shkorbatov, Yu. G. (2017) Investigation of human cell reactions to the effect of low-intensity microwave radiation and a constant magnetic field. Primeneniye lazerov $v$ meditsine $i$ biologiyi: proceedings of the XLVI Internat. sci.-pract. conf. Kharkov, pp. 83-85 [in Russian].

5. Trembovetskaya, R. V. (2012) Analysis of the interaction of laser radiation with biological tissues. Visnyk Cherkaskogo derzhavnogo tehnologichnogo universitetu. Seria: Tehnichni nauky, No. 4, pp. 101-104 [in Russian]. 
6. Builin, V A, Laryushin, A I, Nikitina, M. V. (2004) Light-laser therapy: a guide for doctors. Tver: Triada, 256 p. [in Russian].

7. Ulaschik, V. S., Lukomsky, I. V. (2008) General physiotherapy. $3^{\text {rd }}$ ed., stereotype. Minsk: Knizhnyi Dom, 512 p. [in Russian].

8. URL: www.ledlink-optic.com
9. URL: www.tslc.com.tw

10. Belikov, A. V., Skripnik, A. V. (2008) Laser biomedical technology (part 1). St. Petersburg: SPbGU ITMO, 116 p. [in Russian].

11. Saleh, B., Teich, M. (2012) Optics and photonics. Principles and applications. Vol. 2. Dolgoprudny: Intellect, 784 p. [in Russian].

R. V. Trembovetska, Ph.D., associate professor, e-mail: r.trembovetska@chdtu.edu.ua

V. V. Tychkov, Ph.D., senior lecturer,

Yu. A. Petrushko, magistrant

Cherkasy State Technological University

Shevchenko blvd, 460, Cherkasy, 18006, Ukraine

\section{THE RESEARCH OF MULTICOMPONENT OPTICAL SYSTEM FOR LIGHT-LASER THERAPY}

In this paper one of the methods for calculating a two-component optical system, namely matrix method, is presented. Different variations of optical elements location, such as: irradiated object is located at infinity; light source is located in the front focal plane of lighting system; optical system designs a light source directly to lighting object; lighting system forms the image of the source in the plane of entrance pupil of optical system, are considered. The main goal is to select optical system, which will meet the requirements of technical task. The calculation and analysis of several schemes of a two-component positive optical system are carried out. The conditions are set for the possible fulfillment of the requirements of technical specification and the best that satisfies them is selected.

Key words: light-laser therapy (phototherapy), radiation spectrum, light-emitting diode, wave length, radiation power, optical system, matrix calculation method.

Стаття надійшла 07.03.2018.

Рецензенти: : В. Я. Гальченко, д.т.н., професор,

B. I. Гордієнко, д.т.н., с.н.с. 